\title{
Improving future low-noise aircraft technologies using experimental perception-based evaluation of synthetic flyovers
}

\author{
Reto Pieren ${ }^{\mathrm{a}, *}$, Lothar Bertsch ${ }^{\mathrm{b}}$, Demian Lauper ${ }^{\mathrm{a}}$, Beat Schäffer ${ }^{\mathrm{a}}$ \\ a Empa, Swiss Federal Laboratories for Materials Science and Technology, 8600 Dübendorf, Switzerland \\ b German Aerospace Center (DLR), 37073 Göttingen, Germany
}

\section{H I G H L I G H T S}

- A comprehensive approach to reduce aircraft noise annoyance is proposed.

- Perception-based evaluation of future low-noise aircraft technologies is affirmed.

- Combined optimization of air vehicles and flight procedures is most beneficial.

- Reliable optimization requires consideration of several receiver locations.
G R A P H I C A L A B S T R A C T

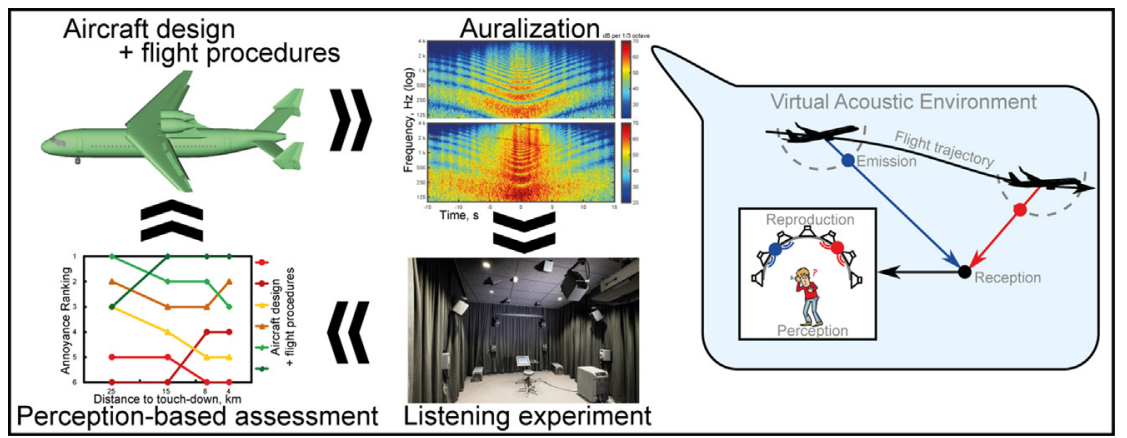

\section{A B S T R A C T}

Residents living in the vicinity of airports are exposed to noise from departing and approaching aircraft Noise may be reduced by introducing novel aircraft technologies into vehicle retrofit, aircraft design and flight procedures. Nowadays, noise assessment and communication of noise are accomplished using conventional noise indicators that consider neither the perception of sound, nor its health effects. To overcome these limitations, this article presents a more comprehensive approach that supports the movement for perception-influenced design in order to reduce the negative environmental impacts and adverse health effects caused by increased air traffic noise. By means of auralization (the acoustical counterpart of visualization), possible future changes can be evaluated by considering the human perception of sound. In this study, in a virtual acoustic environment flyovers of different aircraft types and flight procedures are auralized for ground-based receiver locations, and subsequently evaluated in a psychoacoustic laboratory experiment with respect to short-term noise annoyance. Flight approaches of an existing reference aircraft, a possible low-noise retrofitted vehicle and a future low-noise vehicle design were simulated along standard and tailored flight procedures. To create realistic listening experiences of synthetic flyovers, auralization technologies were further developed regarding source synthesis, transitions between aircraft conditions, sound propagation effects and immersive sound reproduction. Listening experiments revealed significant annoyance reductions for low-noise aircraft types and tailored flight procedures, and that maximum benefit is achieved by the combined optimization of aircraft design and flight procedure. Further, it is shown that spatially distributed receivers need to be considered for a reliable low-noise aircraft technology evaluation. The reduction potential in terms of perceived noise by retrofitting current vehicles and designing new vehicle

\footnotetext{
* Corresponding author.

E-mail address: reto.pieren@empa.ch (R. Pieren).
} 
Finally, with the proposed approach the feasibility of perceptionbased evaluation of future low-noise aircraft technologies could be affirmed. This supports the movement for perception-influenced design in order to reduce the negative environmental impacts and adverse health effects caused by increased (air) traffic noise.

\section{Acknowledgements}

The authors are most grateful to the subjects participating in the listening experiments. The work of Empa was partly funded by the Swiss Federal Office for the Environment (FOEN). The DLR activity was supported via a travel budget by the Projektförderung zur Internationalen Zusammenarbeit (PiZ). Some of the joint work was performed in the context of the research project Aircraft noise Reduction Technologies and related Environmental iMpact (ARTEM), which has received funding from the European Union's Horizon 2020 research and innovation programme under grant agreement No. 769350.

\section{References}

Arntzen, M., Simons, D., 2014. Modeling and synthesis of aircraft flyover noise. Appl. Acoust. 84, 99-106.

Arntzen, M., Bertsch, L., Simons, D., 2015. Auralization of novel aircraft configurations. Proceedings of the 5th CEAS Air and Space Conference, CEAS 2015. The Institute of Acoustics, Delft, Netherlands, pp. 1-11.

Bartels, S., Márki, F., Müller, U., 2015. The influence of acoustical and non-acoustical factors on short-term annoyance due to aircraft noise in the field - the COSMA study. Sci. Total Environ. 538, 834-843.

Basner, M., Babisch, W., Davis, A., Brink, M., Clark, C., Janssen, S., et al., 2014. Auditory and non-auditory effects of noise on health. Lancet 383, 1325-1332.

Bertsch, L., 2013. Noise Prediction Within Conceptual Aircraft Design. DLR Forschungsbericht, ISRN DLRFB-2013-20. German Aerospace Center (DLR), Germany.

Bertsch, L., Heinze, W., Lummer, M., 2014. Application of an aircraft design-to-noise simulation process. 14th AIAA Aviation Technology, Integration, and Operations Conference, AIAA AVIATION Forum, (AIAA 2014-2169). American Institute of Aeronautics and Astronautics, Atlanta https://doi.org/10.2514/6.20142169.

Blinstrub, J., Bertsch, L., Heinze, L., 2018. Assessment of the noise immission along approach and departure flightpaths for different SFB880 vehicle concepts. 2018 AIAA/ CEAS Aeroacoustics Conference. American Institute of Aeronautics and Astronautics, Atlanta https://doi.org/10.2514/6.2018-2818.

Bold, J., Pagnitz, M., 2012. Design of a Silent Leading Edge (SLED). Report, Institut für Faserverbundleichtbau und Adaptronik, Braunschweig, Germany.

Cohen, B.H., 2013. Explaining Psychological Statistics. John Wiley and Sons, Inc, Hoboken, NJ.

Daigle, G., Piercy, J., Embleton, T., 1983. Line-of-sight propagation through atmospheric turbulence near the ground. J. Acoust. Soc. Am. 74 (5), 1505

Deidewig, F., 1998. Ermittlung der Schadstoffemissionen im Unter- und Ueberschallflug. German Aerospace Center, DLR Forschungsbericht, Collogne, Germany, pp. 98-110.

Delany, M.E., Bazley, E.N., 1970. Acoustical properties of fibrous absorbent materials. Appl. Acoust. 3, 105-116.

Delfs, J. (2006). Anordnung eines Aerodynamisches Bauteils mit einer geschlitzten Hinter- oder Seitenkante in einer Stroemung. Deutsches Patent- und Markenamt 2010: Deutsches Patent DE 102006 049616, 21.10.2006.

Dobrzynski, W., 2010. Almost 40 years of airframe noise research: what did we achieve? J. Aircr. 47 (2), 353-367.

Dobrzynski, W.M., Schöning, B., Chow, L., Wood, C., Smith, M., Seror, C., 2006. Design and testing of low noise landing gears. Int. J. Aeroacoust. 5 (3), 233-262.

Dobrzynski, W., Chow, L., Smith, M., Boillot, A., Dereure, O., Molin, N., 2009. Experimental assessment of low noise landing gear component design. 15th AIAA/CEAS Aeroacoustics Conference (30th AIAA Aeroacoustics Conference) (pp. Paper No. 2009-3276). AIAA, Miami, Florida.

Ellermeier, W., Hellbrück, J., Kohlrausch, A., Zeitler, A., 2008. Kompendium zur Durchführung von Hörversuchen in Wissenschaft und industrieller Praxis. Deutsche Gesellschaft für Akustik e.V, Berlin, Germany.

Fields, J., De Jong, R., Gjestland, T., Flindell, I., Job, R., Kurra, S., et al., 2001. Standardized general-purpose noise reaction questions for community noise surveys: research and a recommendation. J. Sound Vib. 242 (4), 641-679.

Gasco, L., Asensio, C., de Arcas, G., 2017. Communicating airport noise emission data to the general public. Sci. Total Environ. 586, 836-848.

Gille, L.-A., Marquis-Favre, C., Weber, R., 2016. Aircraft noise annoyance modeling: consideration of noise sensitivity and of different annoying acoustical characteristics. Appl. Acoust. 115, 139-149.

Groothuis-Oudshoorn, C., Miedema, H., 2006. Multilevel grouped regression for analyzing self-reported health in relation to environmental factors: the model and its application. Biom. J. 48 (1), 67-82.

Guski, R., Schreckenberg, D., Schuemer, R., 2017. WHO environmental noise guidelines for the European region: a systematic review on environmental noise and annoyance. Int. J. Environ. Res. Public Health 14 (2), 1539 (1-14).
Heinze, W., 1994. Ein Beitrag zur quantitativen Analyse der technischen und wirtschaftlichen Auslegungsgrenzen verschiedener Flugzeugkonzepte für den Transport großer Nutzlasten. Technical University Braunschweig (ZLR-Forschungsbericht 94-01, ISBN 3-928628-14-3).

Herr, M., 2007. Design criteria for low-noise trailing edges. 13th AIAA/CEAS Aeroacoustics Conference (28th AIAA Aeroacoustics Conference) (pp. Paper No. 2007-3470). AIAA, Rome, Italy.

Heutschi, K., Pieren, R., Müller, M., Manyoky, M., Wissen Hayek, U., Eggenschwiler, K., 2014. Auralization of wind turbine noise: propagation filtering and vegetation noise synthesis. Acta Acust. Acust. 100, 13-24.

ICAO, International Civil Aviation Organization, 1993. Manual of the Standard ICAO Standard Atmosphere, Doc 7488/3 (Montreal).

ICAO, International Civil Aviation Organization, 2008a. Annex 16 to the Convention on International Civil Aviation - Environmental Protection, Volume I - Aircraft Noise.

ICAO, International Civil Aviation Organization, 2008b. Guidance on the Balanced Approach to Aircraft Noise Management, Doc. 9829. 2nd edition.

ISO, 1993. ISO 9613-1. Acoustics - Attenuation of Sound During Propagation Outdoors Part 1: Calculation of the Absorption of Sound by the Atmosphere. ISO.

Jagla, J., Maillard, J., Martin, N., 2012. Sample-based engine noise synthesis using an enhanced pitch-synchronous overlap-and-add method. J. Acoust. Soc. Am. 132 (5) 3098-3108.

Johnson, P.C., 2014. Extension of Nakagawa \& Schielzeth's R2 GLMM to random slopes models. Methods Ecol. Evol. 5 (9), 944-946.

Kephalopoulos, S., Paviotti, M., Anfosso-Lédée, F., Van Maercke, D., 2014. Advances in the development of common noise assessment methods in Europe: the CNOSSOS-EU framework for strategic environmental noise mapping. Sci. Total Environ. 482-483, $400-410$.

Lindau, A., Weinzierl, S., 2012. Assessing the plausibility of virtual acoustic environments Acta Acust. Acust. 98, 804-810.

Lopes, L.V., Burley, C.L., 2011. Design of the next generation aircraft noise prediction program: ANOPP2. 17th AIAA/CEAS Aeroacoustics Conference. AIAA, Oregon, pp. 2011-2854.

Lummer, M., 2008. Maggi-Rubinowicz diffraction correction for ray-tracing calculations of engine noise shielding. 14th AIAA/CEAS Aeroacoustics Conference.

Meissner, M., 2002. Excitation of Helmholtz resonator by grazing air flow. J. Sound Vib. 382-388.

Nakagawa, S., Schielzeth, H., 2013. A general and simple method for obtaining R2 from generalized linear mixed-effects models. Methods Ecol. Evol. 4 (2), $133-142$.

Nordtest, 2002. NT ACOU 111. Acoustics: Human Sound Perception - Guidelines for Listening Tests (NT ACOU 111). Espoo, Finland, Nordtest.

Pieren, R., Heutschi, K., Müller, M., Manyoky, M., Eggenschwiler, K., 2014. Auralization of wind turbine noise: emission synthesis. Acta Acust. Acust. 100, 25-33.

Pieren, R., Bütler, T., Heutschi, K., 2016. Auralization of accelerating passenger cars using spectral modeling synthesis. Appl. Sci. 6 (5), 1-27.

Pieren, R., Heutschi, K., Wunderli, J., Snellen, M., Simons, D., 2017. Auralization of railway noise: emission synthesis of rolling and impact. Appl. Acoust. 127, 34-45.

Pieren, R., Bertsch, L., Blinstrub, J., Schäffer, B., Wunderli, J., 2018. Simulation Process for Perception-based Noise Optimization of Conventional and Novel Aircraft Concepts. AIAA Science and Technology Forum and Exposition, Florida https://doi.org/ 10.2514/6.2018-0264.

Pott-Pollenske, M., Wild, J., Bertsch, L., 2014. Aerodynamic and acoustic design of silent leading edge devices. 20th AIAA Aeroacoustics Conference. American Institute of Aeronautics and Astronautics, Atlanta https://doi.org/10.2514/6.20142076.

Rizzi, S., 2016. Toward reduced aircraft community noise impact via a perceptioninfluenced design approach. 45th International Congress and Exposition of Noise Control Engineering (InterNoise 2016). Hamburg, Germany.

Rizzi, S., Christian, A., 2016. A psychoacoustic evaluation of noise signatures from advanced civil transport aircraft. 22nd AIAA/CEAS Aeroacoustics Conference (AIAA 2016-2907). AIAA, Lyon, France (p. 16 pp.).

Rizzi, S., Aumann, A., Lopes, L., Burley, C., 2014. Auralization of hybrid wing-body aircraft flyover noise from system noise predictions. J. Aircr. 51 (6), 1914-1926.

Rumsey, F., 2018. Evaluating AVAR - Goodby quality, hello plausibility. J. Audio Eng. Soc 66 (12), 1126-1130.

Sahai, A., Wefers, F., Pick, S., Stumpf, E., Vorländer, M., Kuhlen, T., 2016. Interactive simulation of aircraft noise in aural and visual virtual environments. Appl. Acoust. 101, 24-38.

Schäffer, B., Schlittmeier, S.J., Pieren, R., Heutschi, K., Brink, M., Graf, R., et al., 2016 Short-term annoyance reactions to stationary and time-varying wind turbine and road traffic noise: a laboratory study. J. Acoust. Soc. Am. 139 (5), 2949-2963.

Taghipour, A., Pieren, R., Schäffer, B., 2019. Short-term annoyance reactions to civil helicopter and propeller-driven aircraft noise: a laboratory experiment. J. Acoust. Soc Am. 145 (2), 956-967.

Trolle, A., Marquis-Favre, C., Klein, A., 2014. Short-term annoyance due to tramway noise: determination of an acoustical indicator of annoyance via multilevel regression analysis. Acta Acust. Acust. 100 (1), 34-45.

Vorländer, M., 2008. Auralization - Fundamentals of Acoustics, Modelling, Simulation, Algorithms and Acoustic Virtual Reality. Springer, Berlin.

Wilson, D., Pettit, C., Wayant, N., Nykaza, E., Armstrong, C., 2017. Multilevel modeling and regression of community annoyance to transportation noise. J. Acoust. Soc. Am. 142 (5), 2905-2918.

World Health Organization (WHO), 2018. Environmental Noise Guidelines for the European Region. 
Wunderli, J., Zellmann, C., Köpfli, M., Habermacher, M., Schwab, O., Schlatter, F., et al., 2018. sonAIR - a GIS-integrated spectral aircraft noise simulation tool for single flight prediction and noise mapping. Acta Acust. Acust. 104, S. 440-451.

Zeller, P., 2012. Handbuch Fahrzeugakustik-Grundlagen, Auslegung, Berechnung, Versuch. 2nd ed. Vieweg Teubner Verlag, Wiesbaden, Germany.
Zellmann, C., Jäger, D., Schlatter, F., 2018a. Model adjustment and validation to account for the airflow deflector retrofit of the A320 family. 11th European Congress and Exposition on Noise Control Engineering (Euronoise 2018) (Crete).

Zellmann, C., Schäffer, B., Wunderli, J., Isermann, U., Paschereit, C., 2018b. Aircraft noise emission model accounting for aircraft flight parameters. J. Aircr. 55, 682-695. 